\title{
Body size increase in insular rodent populations: a role for predators?
}

\author{
JOHAN R. MICHAUX*†, JÖ̈LLE GOÜY DE BELLOCQ $\ddagger$, MAURIZIO SARÀ $\$ and SERGE MORAND \\ *Unité de recherches zoogéographiques, University of Liège, Quai Van Beneden, 22, 4020 Liège, Belgium; †Laboratoire de Paléontologie, cc064, \\ Institut des Sciences de l'Evolution, 34095 Montpellier cedex 05, France; $\ddagger$ Laboratoire de Biologie Animale (UMR 5555 CNRS), Centre de \\ Biologie et d'Ecologie Tropicale et Méditerranéenne, Université de Perpignan, Avenue de Villeneuve, 66860 Perpignan Cedex, France; \\ \$Dipartimento di Biologia Animale, via Archirafi, 1890123 Palermo, Italy
}

\begin{abstract}
Insular mammalian populations living in areas of small size are often characterized by a drastic change in body mass compared to related continental populations or species. Generally, small mammals (less than $100 \mathrm{~g}$ ) evolve into giant forms while large mammals (up to $100 \mathrm{~g}$ ) evolve into dwarf forms. These changes, coupled with changes in other life, behavioural, physiological or demographic traits are referred to generally as the insular syndrome. We tested in this study the relative contribution of three factors - area of island, numbers of competitor species and number of
\end{abstract}

predator species - to changes in body size of the woodmouse (Apodemus sylvaticus) in the Western Mediterranean Sea. Our results, based on a comparative analysis using the phylogenetic independent contrasts method, indicate that the increase in body size is related both to the decrease of island size and to the lower number of predator species. A decrease of competitor species does not seem to have an important effect.

Key words Apodemus sylvaticus, body size, comparative analyses, genetic distances, insular syndrome, islands, rodents, predators, Western Mediterranean.

\section{INTRODUCTION}

The distribution of animal body size and the changes in body size of insular populations compared to mainland populations have stimulated a large number of theoretical and empirical studies (Case, 1978; Brown, 1984, 1995; Lomolino, 1985; Angerbjörn, 1986; Brown et al., 1993; Damuth, 1993; Adler \& Levins, 1994).

Island populations live in small areas isolated from continental populations. The degree of isolation, i.e. the decrease in genetic exchanges, may lead these populations to differentiate greatly from their closely related continental populations, giving rise to new species. The main characteristic of island mammal populations is the often drastic change in body mass compared to that of related continental populations or species. Insular populations of mammals that on continents are smaller than $100 \mathrm{~g}$ evolve typically into giant forms, whereas those that are larger than $100 \mathrm{~g}$ on continents evolve into dwarf forms (Van Valen, 1973; Lomolino, 1985). Thus,

Correspondence: Johan R. Michaux, Unité de recherches zoogéographiques, University of Liège, Quai Van Beneden, 22, 4020 Liège, Belgium. E-mail: Johan.Michaux@ulg.ac.be according to Brown (1995), a single species living on a tiny island should tend to approach the optimum mean body size of $100 \mathrm{~g}$.

Gigantism is observed generally in rodents and insectivores, whereas dwarfism concerns larger species such as artiodactylids or perissodactylids (Thaler, 1973; Vigne et al., 1993). These changes in body mass seem to occur very quickly. Roth (1990) reported that elephants on Sicily and Malta decreased in body mass by an order of magnitude in a few thousand years. In the same way, Atchley et al. (1982) showed that it was possible to select giant forms of Rattus rattus in only 23 generations in the laboratory. These changes, which involve modifications in life history, behavioural (Gliwicz, 1980; Takada, 1985; Granjon \& Cheylan, 1988, 1990; Perret \& Blondel, 1993; Adler \& Levins, 1994; Blondel, 1995), physiological or demographic (Poitevin, 1984; Blondel et al., 1992; Fons et al., 1995) traits are referred to generally as the insular syndrome. The determinism of these modifications is probably complex and involves numerous factors, which are difficult to dissociate. Nevertheless, several general hypotheses have been proposed to explain these phenomena.

Grant (1985) suggested that founder events, i.e. the colonization by a low number of immigrants, could play an important 
role in insular differentiation. However, recent genetic studies (Michaux et al., 1996b) have shown that this is not always the case and that ecological factors such as the lower number of competitors or predators may be more important. This hypothesis is corroborated by other studies (Van Valen, 1973; Case, 1978; Lomolino, 1985; Angerbjörn, 1986). In addition, several authors (Carlquist, 1974; Case, 1978; Heaney, 1978; Wassersug et al., 1979; Sarà \& Casamento, 1995) have shown that the area size of the island and the degree of isolation of the population from sources of immigrants could also have an important impact on the occurrence of the insular syndrome. This last factor can be estimated by a measure of genetic isolation, i.e. gene flow.

Our aim is to test the relative contribution of three factors: the area size of the island, the number of species of competitors, and the number of species of predators, to changes in body size of the woodmouse (Apodemus sylvaticus) in the Western Mediterranean Sea. We used the independent contrasts method in order to take into account the genetic distances among populations.

\section{MATERIALS AND METHODS}

\section{Data on woodmouse populations}

Genetic distances between populations were obtained from Michaux et al. (1996a,b, 1998a,b) (Table 1). Geographic distances among all pairs of islands and peninsulas were obtained from maps (Fig. 1a).

Island populations of woodmice have been considered as giant forms on the basis of cranial morphometric analyses (Michaux, 1996; Michaux et al., 1996b) and of classical morphological data (Felten \& Storch, 1970; Kahmann \& Niethammer, 1971; Sans-Coma \& Kahmann, 1977; Alcover \& Gozalbez, 1988; Libois \& Fons, 1990; Libois, unpublished data). Data on body size were obtained from Michaux (1996). Mean body mass of continental populations is approximately $23 \mathrm{~g}$ ( $25 \mathrm{~g}$ on Iberian peninsula and $23 \mathrm{~g}$ for Italy). In several islands the mean body mass is more than $30 \mathrm{~g}$ : Mallorca (35 g), Ibiza (29 g) and Marettimo (30 g) (Fig. 1).

\section{Competitor and predator species account}

We used published data from European and national atlases or check-lists, to obtain the numbers of competitor and predator species present in the studied areas (Arnold \& Burton, 1978; Schilling et al., 1986; Lo Valvo et al., 1993; Meschini \& Frugis, 1993; Yeatman-Berthelot \& Jarry, 1994; Michaux et al., 1996b; Hagemeijer \& Blair, 1997; Sarà, 1998; Mitchell-Jones et al., 1999). Quantitative data of predation on A. sylvaticus were checked in synopses and reviews dealing with the food habits of the European fauna. The main references were: Cramp \& Simmons, 1977-1993, Mikkola (1983), Hancock \& Kushlan (1984), Gensbøl (1992), Meyburg et al. (1998). Only breeding birds and not recently introduced mammals (i.e. Callosciurus, Tamias) were considered. Some very rare (e.g. Pica pica in Sardinia or Hieraaetus fasciatus in Calabria) or marginal (e.g. Microtus savii in South-eastern France) distributions were not listed. The resulting list of species, interacting as competitors or predators with the wood mouse, is reported in Table 2.

\section{Statistical analyses}

Mantel test between geographical distances and genetic distances

Two variables, geographical distance and genetic distance between pairs of $A$. sylvaticus populations were in the form of

Table I Genetic distances (\%) (Nei \& Li, 1979) between insular and continental European populations of woodmice (Apodemus sylvaticus). From Michaux et al. (1996a,b, 1998a,b)

\begin{tabular}{|c|c|c|c|c|c|c|c|c|c|c|c|c|}
\hline & Italy & Spain & Corsica & Sardinia & Elba & Sicily & Mallorca & Menorca & Ibiza & $\begin{array}{l}\text { Porque- } \\
\text { rolles }\end{array}$ & $\begin{array}{l}\text { Port } \\
\text { Cros }\end{array}$ & Maretimo \\
\hline Italy & - & & & & & & & & & & & \\
\hline Spain & 2.6 & - & & & & & & & & & & \\
\hline Corsica & 1.37 & 2.7 & - & & & & & & & & & \\
\hline Sardinia & 1.49 & 2.45 & 1.27 & - & & & & & & & & \\
\hline Elba & 0 & 2.6 & 0.84 & 1 & - & & & & & & & \\
\hline Sicily & 3.7 & 2.9 & 3.3 & 3.5 & 3.7 & - & & & & & & \\
\hline Mallorca & 2.6 & 1.3 & 2.7 & 2.6 & 2.5 & 2.9 & - & & & & & \\
\hline Menorca & 2.3 & 1.2 & 2.3 & 2.4 & 2.3 & 2.7 & 0.5 & - & & & & \\
\hline Ibiza & 2.3 & 1.1 & 2.3 & 2.5 & 2.3 & 2.8 & 0.65 & 0.3 & - & & & \\
\hline Porquerolles & 2.6 & 1.1 & 2.5 & 2.6 & 2.6 & 2.7 & 1.3 & 1.3 & 1.1 & - & & \\
\hline Port Cros & 2.6 & 1.47 & 2.7 & 2.7 & 2.6 & 2.5 & 1.4 & 1.5 & 1.45 & 1.4 & - & \\
\hline Marettimo & 3.7 & 2.9 & 2.93 & 2.91 & 3.7 & 0 & 2.9 & 2.8 & 2.8 & 2.9 & 2.9 & - \\
\hline
\end{tabular}




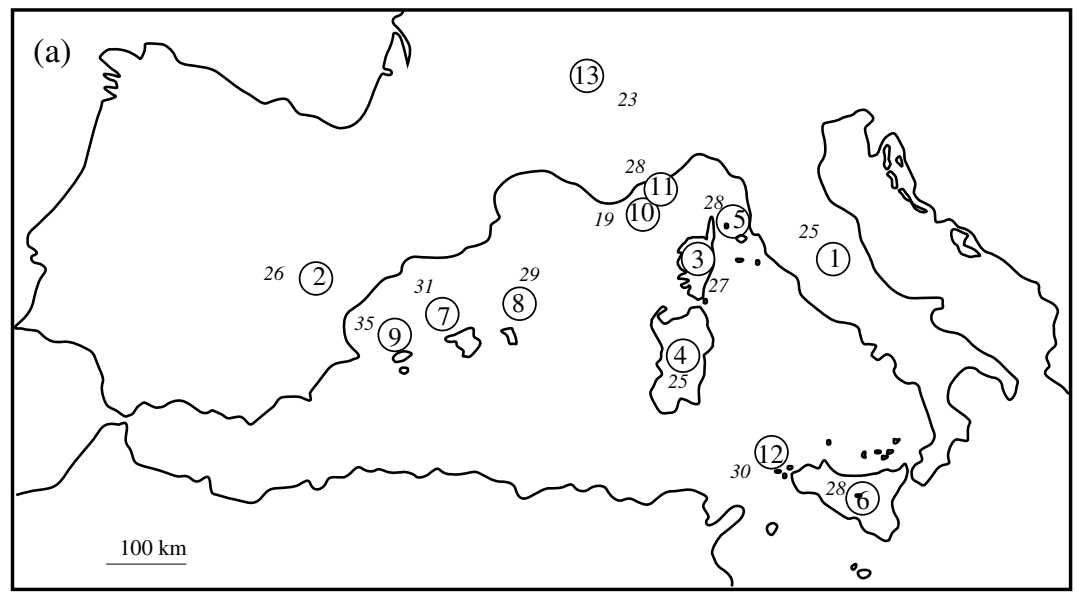

(b)

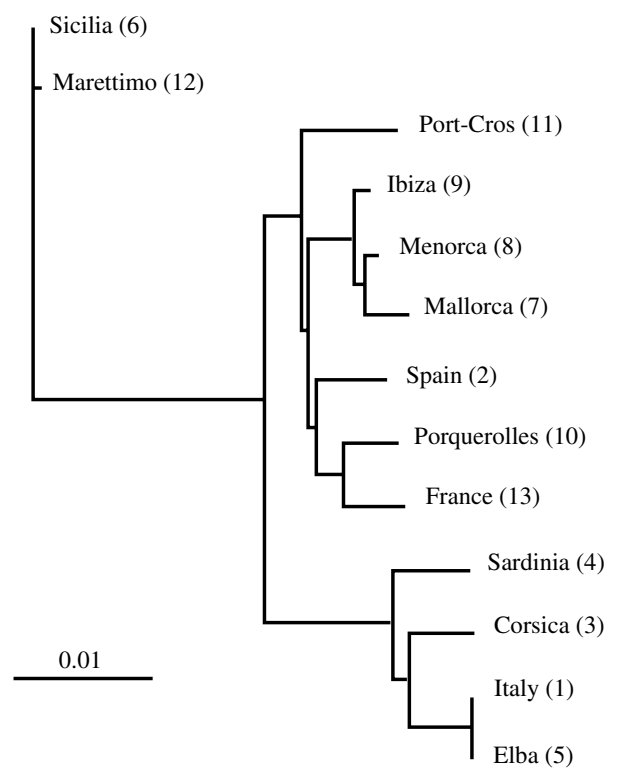

Fig. I (a) Geographic origins of sampled populations of Apodemus sylvaticus. (b) Tree of genetic distances of sampled populations of A. sylvaticus (see Table 2) (numbers in circles refer to location on maps, numbers in italic refer to average body size of A. sylvaticus, from Michaux, 1996).

matrices. Permutation methods are used widely in population biology (Manly, 1991) and allow one to investigate correlation between distance matrices (Legendre et al., 1994). We used the program Permute 3.4 (by P. Casgrain, available at htpp://alize.ere.umontreal.ca/ casgrain/). Correlation was repeated after each of 999 random permutations of the dependent variable (i.e. geographical distance) matrix.

\section{Independent contrasts method}

We used the phylogenetically independent contrasts method (Felsenstein, 1985; Harvey \& Pagel, 1991; Garland et al., 1992; Harvey, 1996) in order to resolve the problem of non- independence of data (i.e. traits measured across different populations of the same species). The independent contrasts method is used for interspecific comparative analyses. Populations, like species, are also linked by historical events and it is then necessary to control for genetic information in an intraspecific comparative analysis in order to avoid potential historical confounding effects (i.e. here phylogeography) (see Garland \& Adolph, 1994). This can be achieved by taking into account the genetic distances between studied populations.

The genetic distances between pairs of populations were used to obtain a tree (Fig. 1b). We used the CAIC computer application (Purvis \& Rambaut, 1995) for independent contrasts analyses. Quantitative data were logarithmically 
Table 2 Geographic origins of Apodemus sylvaticus populations with island/region area, competitor and predator species. Accidental predators are those reported in single cases or papers to prey upon A. sylvaticus with very low frequency (0.01-0.05\% of the investigated prey samples). Nomenclature follows Wilson \& Reeder (1993) for mammals, Arnold \& Burton (1978) for reptiles, and Yeatman-Berthelot \& Jarry (1994) for birds

\begin{tabular}{|c|c|c|c|c|c|c|c|c|c|c|c|c|c|}
\hline $\begin{array}{l}\text { Locations } \\
\text { (see map, Fig. 1a) }\end{array}$ & $\begin{array}{l}\text { France } \\
(13)\end{array}$ & $\begin{array}{l}\text { Italy } \\
(1)\end{array}$ & $\begin{array}{l}\text { Spain } \\
(2)\end{array}$ & $\begin{array}{l}\text { Corsica } \\
\text { (3) }\end{array}$ & $\begin{array}{l}\text { Sardinia } \\
(4)\end{array}$ & $\begin{array}{l}\text { Elbe } \\
(5)\end{array}$ & $\begin{array}{l}\text { Sicily } \\
(6)\end{array}$ & $\begin{array}{l}\text { Mallorca } \\
\text { (7) }\end{array}$ & $\begin{array}{l}\text { Menorca } \\
(8)\end{array}$ & $\begin{array}{l}\text { Ibiza } \\
(9)\end{array}$ & $\begin{array}{l}\text { Porquerolles } \\
\text { (10) }\end{array}$ & $\begin{array}{l}\text { Port-Cros } \\
\text { (11) }\end{array}$ & $\begin{array}{l}\text { Marettimo } \\
\text { (12) }\end{array}$ \\
\hline Area $\left(\mathrm{km}^{2}\right)$ & 500000 & 252000 & 490000 & 8722 & 23833 & 224 & 25460 & 3640 & 702 & 541 & 12.5 & 6.4 & 12.1 \\
\hline \multicolumn{14}{|l|}{ (a) Competitor species } \\
\hline Mus spretus & $\mathrm{y}$ & & $\mathrm{y}$ & & & & & $\mathrm{y}$ & $\mathrm{y}$ & $\mathrm{y}$ & & & \\
\hline Apodemus agrarius & & y & & & & & & & & & & & \\
\hline Apodemus flavicollis & $\mathrm{y}$ & y & $\mathrm{y}$ & & & & & & & & & & \\
\hline Micromys minutus & y & y & y & & & & & & & & & & \\
\hline Arvicola terrestris & y & y & $\mathrm{y}$ & & & & & & & & & & \\
\hline Clethrionomys glareolus & y & y & y & & & & & & & & & & \\
\hline Microtus arvalis & y & y & y & & & & & & & & & & \\
\hline Microtus agrestis & $\mathrm{y}$ & y & y & & & & & & & & & & \\
\hline Microtus duodecimcostatus & $\mathrm{y}$ & & $\mathrm{y}$ & & & & & & & & & & \\
\hline Microtus cabrerae & & & y & & & & & & & & & & \\
\hline Microtus subterraneus & $\mathrm{y}$ & y & & & & & & & & & & & \\
\hline Microtus multiplex & $\mathrm{y}$ & y & & & & & & & & & & & \\
\hline Microtus pyrenaicus & y & & y & & & & & & & & & & \\
\hline Chionomys nivalis & $\mathrm{y}$ & $\mathrm{y}$ & $\mathrm{y}$ & & & & & & & & & & \\
\hline Microtus lusitanicus & $\mathrm{y}$ & & y & & & & & & & & & & \\
\hline Microtus savii & & $\mathrm{y}$ & & & & & $\mathrm{y}$ & & & & & & \\
\hline Microtus gerbei & $\mathrm{y}$ & & y & & & & & & & & & & \\
\hline Sciurus vulgaris & y & y & y & & & & & & & & & & \\
\hline Muscardinus avellanarius & $\mathrm{y}$ & y & & & & & & & & & & & \\
\hline Dryomys nitedula & & y & & & & & & & & & & & \\
\hline Glis glis & $\mathrm{y}$ & y & $\mathrm{y}$ & y & $\mathrm{y}$ & $\mathrm{y}$ & y & & & & & & \\
\hline Eliomys quercinus & $\mathrm{y}$ & y & y & y & y & & y & $\mathrm{y}$ & y & & & & \\
\hline Rattus rattus & y & y & y & y & y & y & y & y & y & $\mathrm{y}$ & $\mathrm{y}$ & $\mathrm{y}$ & y \\
\hline Mus domesticus & $\mathrm{y}$ & y & y & y & y & y & y & y & $\mathrm{y}$ & y & y & y & y \\
\hline (b) Regular predator species & & & & & & & & & & & & & \\
\hline Vulpes vulpes & $\mathrm{y}$ & y & y & y & y & & y & & & & & & \\
\hline Genetta genetta & y & & y & & & & & y & & y & & & \\
\hline Felis silvestris & y & $\mathrm{y}$ & $\mathrm{y}$ & y & y & & $\mathrm{y}$ & & & & & & \\
\hline Martes martes & y & y & y & y & y & $\mathrm{y}$ & y & $\mathrm{y}$ & $\mathrm{y}$ & & & & \\
\hline Mustela nivalis & $\mathrm{y}$ & y & $\mathrm{y}$ & y & y & & y & $\mathrm{y}$ & y & & & & \\
\hline Martes foina & $\mathrm{y}$ & y & y & & & & & & & & & & \\
\hline Mustela putorius & $\mathrm{y}$ & y & y & & & & & & & & & & \\
\hline Mustela erminea & y & y & y & & & & & & & & & & \\
\hline Meles meles & y & y & y & & & & & & & & & & \\
\hline Herpestes ichneumon & & & y & & & & & & & & & & \\
\hline Bubo bubo & y & $\mathrm{y}$ & y & & & & & & & & & & \\
\hline Strix aluco & $\mathrm{y}$ & y & y & & & & $\mathrm{y}$ & & & & & & \\
\hline
\end{tabular}




\begin{tabular}{|c|c|c|c|c|c|c|c|c|c|c|c|c|c|}
\hline $\begin{array}{l}\text { Locations } \\
\text { (see map, Fig. 1a) }\end{array}$ & $\begin{array}{l}\text { France } \\
(13)\end{array}$ & $\begin{array}{l}\text { Italy } \\
(1)\end{array}$ & $\begin{array}{l}\text { Spain } \\
(2)\end{array}$ & $\begin{array}{l}\text { Corsica } \\
\text { (3) }\end{array}$ & $\begin{array}{l}\text { Sardinia } \\
(4)\end{array}$ & $\begin{array}{l}\text { Elbe } \\
(5)\end{array}$ & $\begin{array}{l}\text { Sicily } \\
\text { (6) }\end{array}$ & $\begin{array}{l}\text { Mallorca } \\
\text { (7) }\end{array}$ & $\begin{array}{l}\text { Menorca } \\
(8)\end{array}$ & $\begin{array}{l}\text { Ibiza } \\
(9)\end{array}$ & $\begin{array}{l}\text { Porquerolles } \\
\text { (10) }\end{array}$ & $\begin{array}{l}\text { Port-Cros } \\
\text { (11) }\end{array}$ & $\begin{array}{l}\text { Marettimo } \\
(12)\end{array}$ \\
\hline Asio otus & y & $\mathrm{y}$ & $\mathrm{y}$ & y & & & $\mathrm{y}$ & y & & & & & \\
\hline Athene noctua & $\mathrm{y}$ & $\mathrm{y}$ & $\mathrm{y}$ & $\mathrm{y}$ & $\mathrm{y}$ & $\mathrm{y}$ & $\mathrm{y}$ & y & & & & & \\
\hline Tyto alba & $\mathrm{y}$ & $\mathrm{y}$ & $\mathrm{y}$ & y & $\mathrm{y}$ & $\mathrm{y}$ & $\mathrm{y}$ & $\mathrm{y}$ & $\mathrm{y}$ & $\mathrm{y}$ & $\mathrm{y}$ & & y \\
\hline Otus scops & $\mathrm{y}$ & $\mathrm{y}$ & $\mathrm{y}$ & $\mathrm{y}$ & $\mathrm{y}$ & $\mathrm{y}$ & $\mathrm{y}$ & $\mathrm{y}$ & $\mathrm{y}$ & & & & $\mathrm{y}$ \\
\hline Glaucidium passerinum & y & $\mathrm{y}$ & & & & & & & & & & & \\
\hline Asio flammeus & $\mathrm{y}$ & & $\mathrm{y}$ & & & & & $\mathrm{y}$ & $\mathrm{y}$ & & & & \\
\hline Aegolius funereus & y & $\mathrm{y}$ & & & & & & & & & & & \\
\hline Buteo buteo & y & $\mathrm{y}$ & $\mathrm{y}$ & y & $\mathrm{y}$ & & $\mathrm{y}$ & & & & & & y \\
\hline Circaetuus gallicus & y & $\mathrm{y}$ & $\mathrm{y}$ & & & & & & & & & & \\
\hline Accipiter gentilis & y & $\mathrm{y}$ & $\mathrm{y}$ & y & $\mathrm{y}$ & & & & & & & & \\
\hline Accipiter nisus & y & $\mathrm{y}$ & $\mathrm{y}$ & y & $\mathrm{y}$ & & $\mathrm{y}$ & & & & & & \\
\hline Aquila chrysaetos & y & $\mathrm{y}$ & y & y & $\mathrm{y}$ & & $\mathrm{y}$ & & & & & & \\
\hline Hieraaetus pennatus & y & & $\mathrm{y}$ & & & & & $\mathrm{y}$ & $\mathrm{y}$ & & & & \\
\hline Falco tinnunculus & y & $\mathrm{y}$ & $\mathrm{y}$ & y & y & $\mathrm{y}$ & y & $\mathrm{y}$ & y & y & y & & y \\
\hline Falco biarmicus & & $\mathrm{y}$ & & & & & $\mathrm{y}$ & & & & & & \\
\hline Falco naumanni & & $\mathbf{y}$ & $\mathrm{y}$ & & $\mathrm{y}$ & & y & & & & & & \\
\hline Falco subbuteo & $\mathrm{y}$ & $\mathrm{y}$ & $\mathrm{y}$ & y & y & & $\mathrm{y}$ & y & & & & & \\
\hline Milvus milvus & y & $\mathrm{y}$ & $\mathrm{y}$ & y & $\mathrm{y}$ & & $\mathrm{y}$ & y & $\mathrm{y}$ & & & & \\
\hline Milvus migrans & y & $\mathrm{y}$ & $\mathrm{y}$ & & & & $\mathrm{y}$ & & & & & & \\
\hline Elanus caeruleus & & & $\mathrm{y}$ & & & & & & & & & & \\
\hline Circus cyaneus & y & & $\mathrm{y}$ & & & & & & & & & & \\
\hline Burhinus oedicnemus & $\mathrm{y}$ & $\mathrm{y}$ & $\mathrm{y}$ & & $\mathrm{y}$ & & $\mathrm{y}$ & $\mathrm{y}$ & $\mathrm{y}$ & & & & \\
\hline Lanius excubitor & y & & $\mathrm{y}$ & & & & & & & & & & \\
\hline Lanius collurio & y & $\mathrm{y}$ & $\mathrm{y}$ & y & $\mathrm{y}$ & $\mathrm{y}$ & $\mathrm{y}$ & & & & & & \\
\hline Lanius senator & y & $\mathrm{y}$ & $\mathrm{y}$ & y & $\mathrm{y}$ & & $\mathrm{y}$ & y & y & & & & \\
\hline Corvus corax & y & $\mathrm{y}$ & $\mathrm{y}$ & $\mathrm{y}$ & $\mathrm{y}$ & $\mathrm{y}$ & $\mathrm{y}$ & y & y & & & & $\mathrm{y}$ \\
\hline Hierophis viridiflavus & y & $\mathrm{y}$ & $\mathrm{y}$ & y & $\mathrm{y}$ & $\mathrm{y}$ & $\mathrm{y}$ & & & & & & y \\
\hline Coluber hippocrepis & & & $\mathrm{y}$ & & $\mathrm{y}$ & & & & & & & & \\
\hline Malpolon monspessulanus & $\mathrm{y}$ & $\mathrm{y}$ & $\mathrm{y}$ & & & & & & & & $\mathrm{y}$ & & \\
\hline Natrix natrix & y & $\mathrm{y}$ & $\mathrm{y}$ & $\mathrm{y}$ & $\mathrm{y}$ & & $\mathrm{y}$ & & & & & & \\
\hline Coronella austriaca & y & $\mathrm{y}$ & $\mathrm{y}$ & & & & y & & & & & & \\
\hline Coronella girondica & $\mathrm{y}$ & $\mathrm{y}$ & $\mathrm{y}$ & & & & & & & & & & \\
\hline Vipera aspis & y & $\mathrm{y}$ & $\mathrm{y}$ & & & $\mathrm{y}$ & $\mathrm{y}$ & & & & & & \\
\hline Vipera ursinii & $\mathrm{y}$ & $\mathrm{y}$ & & & & & & & & & & & \\
\hline Vipera berus & $\mathrm{y}$ & $\mathrm{y}$ & & & & & & & & & & & \\
\hline Vipera latasti & & $\mathrm{y}$ & & & & & & & & & & & \\
\hline Vipera seoanei & & & $\mathrm{y}$ & & & & & & & & & & \\
\hline Elaphe scalaris & $\mathrm{y}$ & & $\mathrm{y}$ & & & & & & $\mathrm{y}$ & & $\mathrm{y}$ & & \\
\hline Elaphe situla & & $\mathrm{y}$ & & & & & $\mathrm{y}$ & & & & & & \\
\hline Elaphe quatuorlineata & & $\mathrm{y}$ & & & & & & & & & & & \\
\hline Elaphe longissima & $\mathrm{y}$ & $\mathrm{y}$ & $\mathrm{y}$ & & $\mathrm{y}$ & & y & & & & & & \\
\hline
\end{tabular}




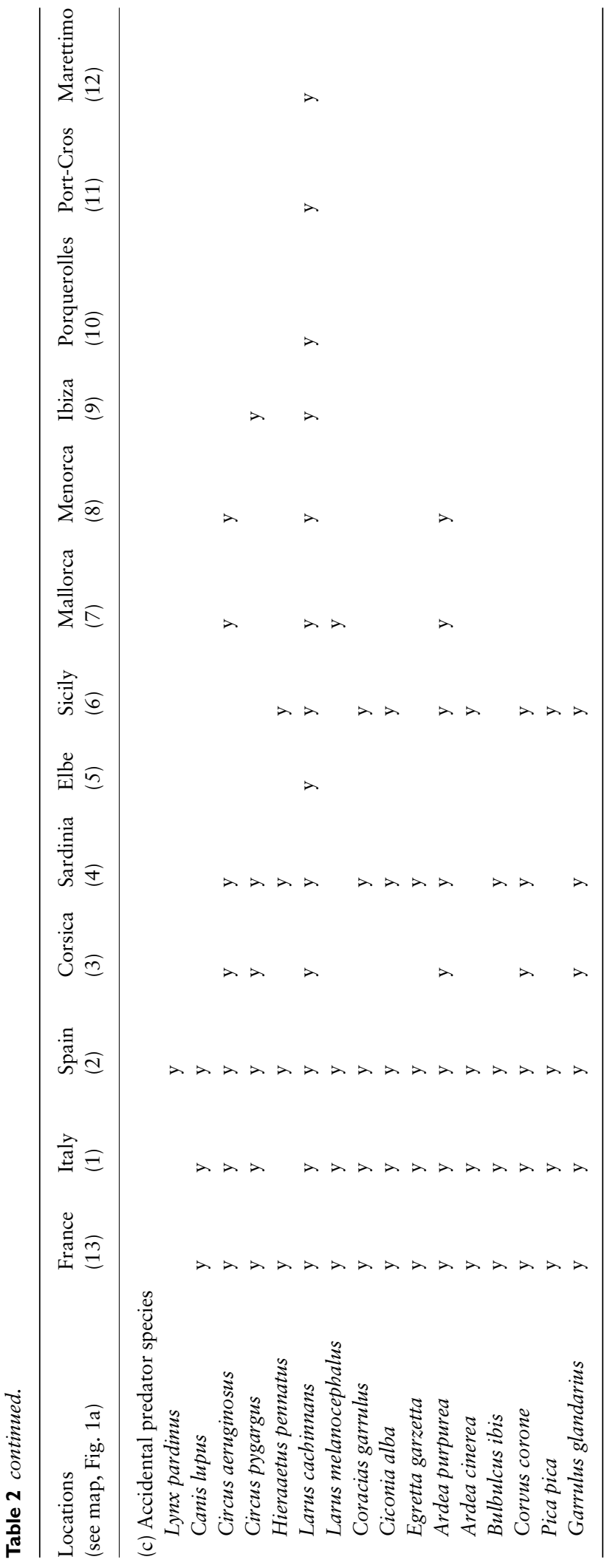

transformed in order to stabilize variance (Harvey, 1982). All regressions between contrasts were forced through the origin (Garland et al., 1992). In order to verify that contrasts were standardized properly we performed a regression of the absolute values of standardized contrasts vs. their standard deviations (Garland et al., 1992) using CAIC.

\section{RESULTS}

We found a significant positive relationship between geographical distances and genetic distances using the permutation test, showing that geographical isolation of A. sylvaticus populations was related to a decrease in genetic exchanges $(r=0.57, P=0.001)$. The position of the population of PortCros can be noted between the Italian group (Italy, Sicilia, Corsica, Elba) and the Iberian (Spain, Balearics) and French (France, Porquerolles) groups.

Using the whole dataset, we found that A. sylvaticus body size is not related to area of source region/island $(r=-0.098$, $P=0.75$; Fig. 2a). However, this lack of correlation was due to one point (Port-Cros). The regression was statistically significant when this outlier was removed $(r=-0.632, P=$ 0.028; Fig. 2a). Significant correlations were found between A. sylvaticus body size and area $(r=-0.71, P=0.0098)$, number of regular predator species and area $(r=0.94$, $P<0.0001)$, number of occasional predator species and area $(r=0.98, P<0.0001)$ and number of competitor species and area size $(r=0.95, P<0.0001)$ using independent contrasts.

We controlled for body size, total number of predator species (occasional and regular) and the number of competitor species in relation to area by using the residuals of the preceding regressions using independent contrasts. We found a negative correlation between the residuals of body size (controlled for area) and the residuals of the total number of predator species (controlled for area) using independent contrasts $(r=-0.76, P=0.0045$, Fig. $2 b)$. A similar negative relationship was found using the number of regular predator species $(r=-0.74, P=0.0063)$. These results suggest that the changes in body size of A. sylvaticus depend on predator pressures (irrespective of area of source region/island).

No correlation was found between the residuals of body size (controlled for area) and the residuals of the number of competitor species (controlled for area) using independent contrasts $(r=-0.237, P=0.46)$.

When using the raw data (i.e. not controlled for genetic distances), a negative trend (also not statistically significant) was found between the residuals of body size (controlled for area) and the residuals of the number of competitor species (controlled for area) $(r=-0.54, P=0.07$, Fig. 2c).

We confirmed these findings by performing a multiregression using the permutation method (Legendre \& Legendre, 1998). Using a backward procedure, this method allows the selection of a subset of explanatory (i.e. independent) 

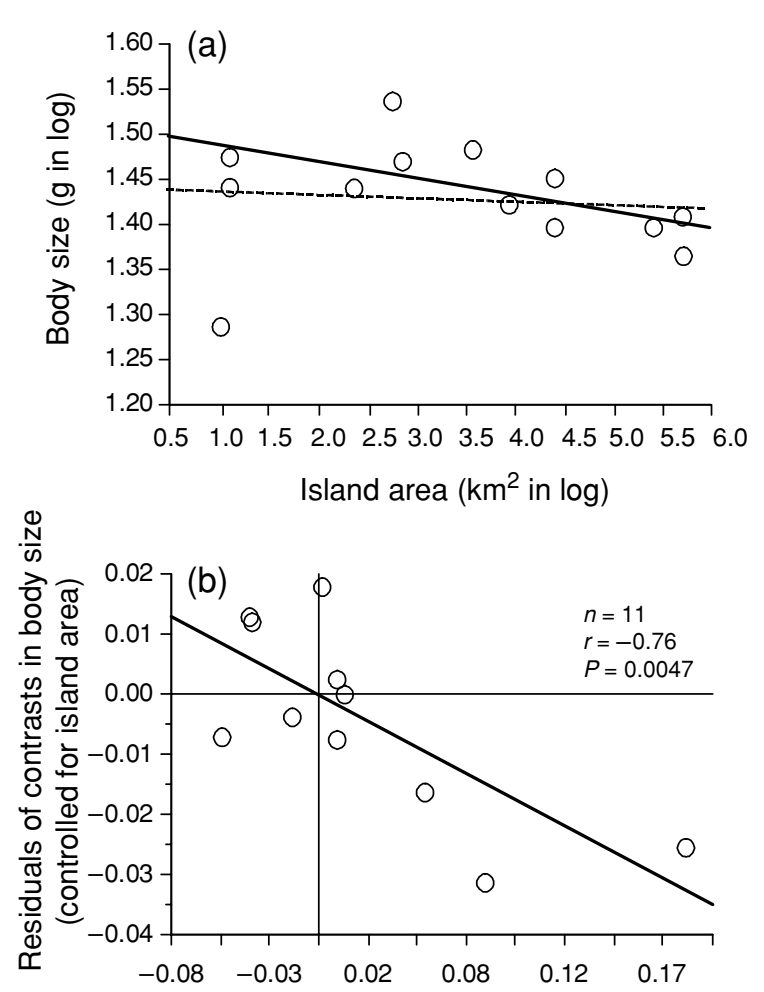

Residuals of contrasts in sum of predator species (controlled for island area)

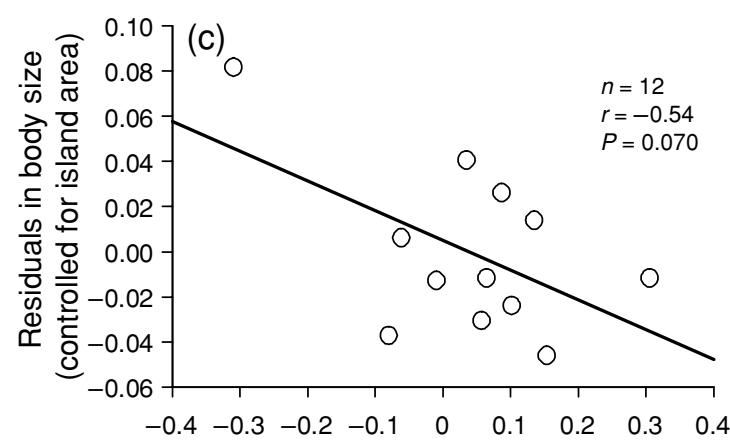

Residuals in sum of competitor species (controlled for island area)

Fig. 2 (a) Relationship between island area and average body size of Apodemus sylvaticus. Two regressions were obtained. The significant one (dashed line) was obtained when the outlier Port-Cros (left bottom point) was removed from the analysis. (b) Relationship between the residuals of body size of A. sylvaticus (controlled for island area) and the residuals of numbers of predator species (controlled for island area) using independent contrasts. (c) Relationship between the residuals of body size of A. sylvaticus (controlled for island area) and the residuals of numbers of competitor species (controlled for island area) using raw data. variables. These variables were the contrasts in area, the contrasts in total number of predators and the contrasts in total number of competitors. Using the whole dataset, we found that only the total number of predators was correlated with body size $(P=0.04)$. Removing the outlier, we found that both area (partial $P=0.027$ ) and total number of predators (partial $P=0.010)$ were correlated with body size $(P=0.033)$.

\section{DISCUSSION}

Our comparative analyses using the independent contrasts method show clearly that the increase in body size of A. sylvaticus occurred on small islands with a low number of predator species. In general, the explanation for the relationship between increase in body size of small species and island size is not clear. Melton (1982) and Adler \& Levins (1994) proposed that on small islands, small-bodied species should have higher population densities than on continents or larger islands. Adler \& Levins (1994) suggested that this favours a $K$-strategy, leading to an increase in life span and to a decrease in the number of offspring. This reduces the overall reproductive effort and results in re-allocation of energy to growth and maintenance and then large body size. However, in the case of woodmouse populations on Mediterranean islands, their densities are often lower than those of continental populations (Sarà \& Casamento, 1993; J.R. Michaux, unpublished data). This results probably from competition with the black rat (Rattus rattus) and the house mouse (Mus musculus), wild populations of both of which are present on many Mediterranean islands at high densities (Granjon \& Cheylan, 1988, 1990).

\section{A role for predators}

Our analyses indicate that the number of predator species plays a more important role than the number of competitor species. Indeed, Lawlor (1982) and Lomolino (1985), who associated the appearance of insular gigantism with the number of competitor species, based their hypothesis on the fact that, generally, the number of competitor species is lower on small islands than on continents (see also Alcover \& Gosalbez, 1988). This leads to 'empty' niche space, which will be more easily filled by individuals having a larger size (Lister, 1976). However, in our case the number of competitor species observed on small islands with large-bodied Apodemus is of the same order as those observed on large islands (Corsica, Sicily, Sardinia) where no gigantism is observed (Contoli et al., 1988a,b; Libois \& Fons, 1990). Moreover, the densities of the competitor species (principally $R$. rattus and M. musculus) currently living on the small Mediterranean islands are drastically high (Granjon \& Cheylan, 1988, 1990), which would seem to rule out easy access to the 'free' ecological niche space for the woodmouse. 
In contrast, predator pressure is clearly lower on small islands compared to large islands, where it is similar to the continental regions. The relationship between a lower pressure of predators and insular gigantism could be explained by the following scenario. On large islands or on the continent, small mammals have a greater advantage to be as small as possible to escape from predators. On small islands, with fewer predators but also less habitat diversity and low food reserves (Lawlor, 1982; Angerbjörn, 1986; Cirer \& MartinezRica, 1990), a larger size will have a selective advantage in terms of mechanisms relating to food foraging, territory defence and access to reproduction (Case, 1978; Angerbjörn, 1986). This kind of advantageous character will become fixed if the population size is small and populations are isolated in small areas (Michaux et al., 1996b).

The relationships and the interaction strength between the insular Apodemus and particular predator species are likely to differ. Indeed, only one predator species, the weasel Mustela nivalis, is absent exclusively on the islands where giant individuals of Apodemus are observed. This suggests that the interaction strength between these two species is very considerable and that the absence of the weasel may be a key determinant in the appearance of giant woodmice.

As A. sylvaticus colonized the studied Mediterranean islands at least 2000 years before R. rattus and M. musculus (Reumer \& Sanders, 1984; Vigne, 1992; Audouin-Rouzeau, 1994), an additional hypothesis to explain the woodmouse insular gigantism would be that: firstly, its body size may have evolved in the absence of its principal competitors (through the mechanism of decrease of interspecific competition), and secondly, that the current high population levels of Mus and Rattus may have caused 'unnatural' and very recent depression in the population levels of Apodemus. However, prior to the arrival of Rattus and Mus on the islands, the number of competitor species observed on small islands with largebodied Apodemus was already of the same order as that observed on the large islands where no gigantism is observed (Reumer \& Sanders, 1984; Vigne, 1992). We therefore suggest that a decrease of interspecific competition probably had a low role in the appearance of the insular gigantism in the woodmouse during this period and that our predator pressure scenario retains relevance to the period when Apodemus was not in competition with Rattus and Mus.

Finally, our results also highlight the importance of genetic distances, i.e. genetic isolation, as a significant correlation was found using independent contrasts (taking into account the phylogeographical confounding effects), whereas a lack of significant correlation was found using the raw data. A decrease in gene flow seems to be required for selection for increasing body size to occur.

As the number of predator and competitor species are of the same orders in the North Sea islands where giant woodmice are also observed (St Kilda, Rhum and Fair islands)
(Delany \& Healy, 1964; Delany, 1970), we can postulate that our hypothesis may be generalized to this region. The same reasoning may also be applied for the garden dormouse (Eliomys quercinus) populations from the Mediterranean islands. Indeed, the two islands where giant forms are observed (Lipari and Formentera) are characterized by a significantly lower number of predators, while the number of competitor species is of the same order as on the large Mediterranean islands where no gigantism is observed. Nevertheless, it would be dangerous to extrapolate our hypothesis to other insectivorous or carnivorous small mammals because their predators and competitors are very different.

\section{ACKNOWLEDGMENTS}

This research was supported by a Belgian FNRS fellowship to J. Michaux (mandat 'Chargé de Recherches') and by grants of the FNRS covering field collections in the Mediterranean islands. J. Goüy de Bellocq is supported by a Ministère de la Recherche et de la Technologie fellowship. This study was also supported by the Institut Français de la Biodiversité.

\section{REFERENCES}

Adler, G.H. \& Levins, R. (1994) The island syndrome in rodent populations? Quarterly Review of Biology, 69, 473-490.

Alcover, J.A. \& Gozalbez, J. (1988) Estudio comparado de la fauna de micromammiferos de la Islas Baleares y Pitiusas. Bulletin d'Ecologie, 19, 321-328.

Angerbjörn, A. (1986) Gigantism in island populations of wood mice (Apodemus sylvaticus) in Europe. Oikos, 47, 47-56.

Arnold, E.N. \& Burton, J.A. (1978) Reptiles and amphibians of Britain and Europe. Collins \& Sons, London.

Atchley, W.R., Ruttledge, J.J. \& Cowley, D.E. (1982) A multivariate statistical analysis of direct and correlated response to selection in the rat. Evolution, 36, 677-698.

Audouin-Rouzeau, F. (1994) La colonisation de l'Europe par le rat noir (Rattus rattus). Revue de Paléobiologie, 13, 125-145.

Blackburn, T.M. \& Gaston, K.J. (1996) On being the right size: different definitions of 'right'. Oikos, 75, 551-557.

Blondel, J. (1995) Biogéographie approche écologique et évolutive. Masson, Paris.

Blondel, J., Pradel, R. \& Lebreton, J.D. (1992) Low fecundity insular blue tits do not survive better as adults than high fecundity mainland ones. Journal of Animal Ecology, 61, 205-213.

Brown, J.H. (1984) On the relationship between abundance and distribution of species. American Naturalist, 124, 255-279.

Brown, J.H. (1995) Macroecology. University of Chicago Press, Chicago.

Brown, J.H., Marquet, P.A. \& Taper, M.L. (1993) Evolution of body size: consequences of an energetic definition of fitness. American Naturalist, 142, 573-584.

Carlquist, S. (1974) Island biology. Columbia University Press, New York.

Case, T.J. (1978) A general explanation for insular body size trends in terrestrial vertebrates. Ecology, 59, 1-18. 
Cirer, A.M. \& Martinez-Rica, J.P. (1990) The polymorphism of Podarcis pityusensis and its adaptative evolution in the Mediterranean islands. Herpetological Journal, 1, 465-473.

Contoli, L., Aloise, G. \& Filippucci, M.G. (1988a) Sulla diversificazione trofica di Barbagiani Tyto alba e Civetta Athene noctua in rapporto al livello diagnostico delle prede. Avocetta, 12, 2130.

Contoli, L., Aloise, G. \& Filippucci, M.G. (1988b) Sulla nicchia di Tyto alba e Athene noctua nell'isola d'Elba (Toscana) in rapporto all'Italia Tirrenica. Bulletin d'Ecologie, 19, 367-373.

Cramp, S. \& Simmons, K.E.L. (1977-93) The birds of the Western Palearctic, vols I-IV and VII. Oxford University Press, Oxford.

Damuth, J. (1993) Cope's rule, the island rule and the scaling of mammalian population density. Nature, $365,748-750$.

Delany, M.J. (1970) Variation and ecology of island populations of the long tailed field mouse (Apodemus sylvaticus). Symposia of the Zoological Society of London, 26, 283-295.

Delany, M.J. \& Healy, M.J.R. (1964) Variation in the long tailed field mouse (Apodemus sylvaticus) in the Channel Isles. Proceedings of the Royal Society of London, B, 166, 408-421.

Felsenstein, J. (1985) Phylogenies and the comparative method. American Naturalist, 125, 1-15.

Felten, H. \& Storch, G. (1970) Kleinsäuger von den italienischen Mittelmeer-Inseln Pantelleria und Lampedusa. Senckenbergiana Biologica, 51, 159-173.

Fons, R., Mas Coma, S., Miquel, J. \& Marchand, B. (1995) Interations durables: mammifères-Helminthes et syndrôme d'insularité. Le cas des îles méditerannéennes. Communication XIX Colloques International Mammalogie, Banyuls/Mer, 13-15 October 1995, 44.

Garland, Jr \& Adolph, S.C. (1994) Why not to do 2-species comparative studies: limitations on inferring adaptation. Physiological Zoology, 67, 797-828.

Garland, T. Jr, Harvey, P.H. \& Ives, A.R. (1992) Procedures for the analysis of comparative data using phylogenetically independent contrasts. Systematic Biology, 41, 18-32.

Gensbøl, B. (1992) Guida ai Rapaci Diurni. Zanichelli, Bologna.

Gliwicz, J. (1980) Island populations of rodents: their organization and functioning. Biological Review, 55, 109-138.

Granjon, L. \& Cheylan, G. (1988) Mécanismes de coexistence dans une guilde de muridés insulaires (Rattus rattus, Apodemus sylvaticus et Mus musculus domesticus) en Corse: conséquences évolutives. Zoologish Saügetierkunde, 53, 301-316.

Granjon, L. \& Cheylan, G. (1990) Différenciation biométrique des rats noirs (Rattus rattus) des îles ouest-méditerranéennes. Mammalia, 54, 213-2323.

Grant, P.R. (1985) The adaptative significance of some insular trends in insular birds. Evolution, 19, 355-368.

Hagemeijer, W.J.M. \& Blair, M.J. (1997) The EBCC atlas of European breeding birds. T. \& A.D. Poyser, London.

Hancock, J. \& Kushlan, J. (1984) The herons handbook. CroomHelm, London and Sidney.

Harvey, P.H. (1982) On rethinking allometry. Journal of Theoretical Biology, 95, 37-41.

Harvey, P.H. (1996) Phylogenies for ecologists. Journal of Animal Ecology, 65, 255-263.

Harvey, P.H. \& Pagel, M. (1991) The comparative method in evolutionary biology. Oxford University Press, Oxford.

Heaney, L. (1978) Island area and body size of insular mammals: evidence from the tri-colored squirrel (Callosciurus prevosti) of southeast Asia. Evolution, 32, 29-44.

Kahmann, H. \& Niethammer, J. (1971) Die waldmous (Apodemus sylvaticus) auf der Insel Elba. Senckenbergiana Biologica, 52, 381-392.

Lawlor, T.E. (1982) The evolution of body size in mammals: evidence from insular populations in Mexico. American Naturalist, 119, 54-72.

Legendre, P., Lapointe, F.G. \& Casgrain, P. (1994) Modeling brain evolution from behavior: a permutational regression approach. Evolution, 48, 1487-1499.

Legendre, P. \& Legendre, L. (1998) Numerical ecology, 2nd English edn. Elsevier Science BV, Amsterdam.

Libois, R. \& Fons, R. (1990) Le mulot des îles d'Hyères: un cas de gigantisme insulaire. Vie et Milieu, 40, 217-222.

Lister, B.C. (1976) The nature of niche expansion in West Indian Anolis lizard. I: Ecological consequences of reduced competition. Evolution, 30, 659-676.

Lo Valvo, M., Massa, B. \& Sarà, M. (1993) Uccelli e paesaggio in Sicilia alle soglie del terzo millennio. Naturalista Sicilia , 17, 3-371.

Lomolino, M.V. (1985) Body size of mammals on islands: the island rule re-examined. American Naturalist, 125, 310-316.

Manly, B.F.J. (1991) Randomization and Monte Carlo methods in biology. Chapman \& Hall, London.

Melton, R.H. (1982) Body size and island Peromyscus: a pattern and a hypothesis. Evolutionary Theory, 6, 113-126.

Meschini, E. \& Frugis, S. (1993) Atlante degli uccelli nidificanti in Italia. Ricerche Biologia Selvaggina, 20 (Suppl.), 3-345.

Meyburg, B., Chanchellor, R.D. \& Ferrero, J.J. (1998) Holoarctic birds of prey. Proceedings of an International Conference. ADENEX-WWGBP, Junta de Extremadura.

Michaux, J. (1996) Biogéographie du mulot sylvestre (Apodemus sylvaticus) dans le bassin méditerranéen occidental: étude génétique de l'origine des peuplements et microévolution en milieu insulaire. Unpublished PhD Thesis, University of Liège.

Michaux, J.R., Filippucci, M.G., Libois, R., Fons, R. \& Matagne, R.F. (1996b) Biogeography and taxonomy of Apodemus sylvaticus (the woodmouse) in the Tyrrhenian region: enzymatic variations and mitochondrial DNA restriction pattern analysis. Heredity, 76, 267-277.

Michaux, J., Libois, R. \& Fons, R. (1996a) Différenciation génétique et morphologique du mulot, Apodemus sylvaticus, dans le bassin méditerranéen occidental. Vie et Milieu 46, 193-203.

Michaux, J.R., Libois, R., Ramalhinho, M.G. \& Maurois, C. (1998a) On the mtDNA restriction patterns variation of the Iberian wood mouse (Apodemus sylvaticus): comparison with other west Mediterranean populations. Hereditas, 129, 187-194.

Michaux, J., Sarà, M., Libois, R.M. \& Matagne, R. (1998b) Is the woodmouse (Apodemus sylvaticus) of Sicily really a 'separate' species? Belgian Journal of Zoology, 128, 211-214.

Mikkola, H. (1983) Owls of Europe. T. \& A.D. Poyser, London.

Mitchell-Jones, A.J., Amori, G., Bogdanowicz, W., Krystufek, B., Reijnders, P.J.H., Spitzenberger, F., Stubb, M., Thissen, J.B.M., Vohralik, V. \& Zima, J. (1999) The atlas of European mammals. T. \& A.D. Poyser, London.

Nei, M. \& Li, W.-H. (1979) Mathematical model for studying genetic variation in terms of restriction endonucleases. Proceedings of the National Academy of Sciences USA, 76, 5269-5273. 
Perret, P. \& Blondel, J. (1993) Experimental evidence of the territorial defense hypothesis in insular blue tits. Experientia, 49, 94-98.

Poitevin, F. (1984) Biogéographie des Crocidures méditerranéennes (Insectivores, Soricidés) Crocidura russula (Herman, 1780) et Crocidura suaveolens (Pallas, 1811). Importance de la compétition interspécifique dans la compréhension de leur distribution. Unpublished PhD Thesis, University of Montpellier.

Purvis, A. \& Rambaut, A. (1995) Comparative analysis by independent contrasts (CAIC): an Apple Macintosh application for analysing comparative data. Computer Applications in the Biosciences, 11, 247-251.

Reumer, J.W.H. \& Sanders, E.A.C. (1984) Changes in the vertebrates fauna of Menorca in prehistoric and classical times. Zeitschrift für Sängetierkunde, 49, 321-325.

Roth, V.L. (1990) Insular dwarf elephants: A case study in body mass estimation and ecological inference. Body size in mammalian paleobiology: estimation and biological implications (ed. by J. Damuth and B.J. MacFadden), pp. 151-179. Cambridge University Press, New York.

Sans-Coma, V. \& Kahmann, H. (1977) Die Waldmous der Pityuseninsel Formentera. Säugetierkunde Mittelmeer, 19, 363-365.

Sarà, M. (1998) I Mammiferi delle Isole del Mediterraneo. L'Epos, Palermo.

Sarà, M. \& Casamento, G. (1993) Grid-trapping of the wood mouse (Apodemus sylvaticus) in a Mediterranean oak-wood (Sicily). Hystrix, 4, 17-27.

Sarà, M. \& Casamento, G. (1995) Geographical variation of the wood mouse (Apodemus sylvaticus, Mammalia, Rodentia) in Western Mediterranean islands: a size-free canonical variate anaylsis. Bolletino di Zoologia, 62, 313-320.

Schilling, D., Singer, D. \& Diller, H. (1986) Guide des mammifères d'Europe. Editions Delachaux et Niestlè, Lausanne.
Takada, Y. (1985) Demography in island and mainland populations of the feral house mouse Mus musculus molossinus. Journal of the Mammalian Society of Japan, 10, 179-191.

Thaler, L. (1973) Nanisme et gigantisme insulaire. La Recherche, 37, 741-750.

Van Valen, L. (1973) Pattern and the balance of nature. Evolutionary Theory, 1, 31-49.

Vigne, J.D. (1992) Zooarchaeology and the Biogeographical history of the mammals of Corsica and Sardinia since the last Ice Age. Mammal Review, 22, 87-96.

Vigne, J.D., Cheylan, G., Granjon, L. \& Auffray, J.C. (1993) Evolution ostéométrique de Rattus rattus et de Mus musculus domesticus sur de petites îles: comparaison de populations médiévales et actuelles des îles Lavezzi (Corse) et de Corse. Mammalia, 57, 85-98.

Wassersug, R.J., Yang, H., Septoski, J.J. \& Raup, D.M. (1979) The evolution of body size on islands: a computer simulation. American Naturalist, 114, 287-295.

Wilson, D.E. \& Reeder, D.M., eds. (1993) Mammal species of the world. Smithsonian Institution Press, Washington.

Yeatman-Berthelot, D. \& Jarry, G. (1994) Nouvel atlas des oiseaux nicheurs de France, 1985-89. Société Ornithologique de France, Paris.

\section{BIOSKETCHES}

J.R. Michaux is presently working on the phylogeography and conservation biology of different European mammal species.

S. Morand and J. Goüy de Bellocq are parasitologists presently working on the effects of isolation in islands on the parasite fauna.

M. Sarà is a mammalogist specializing in the fauna of Sicily. 